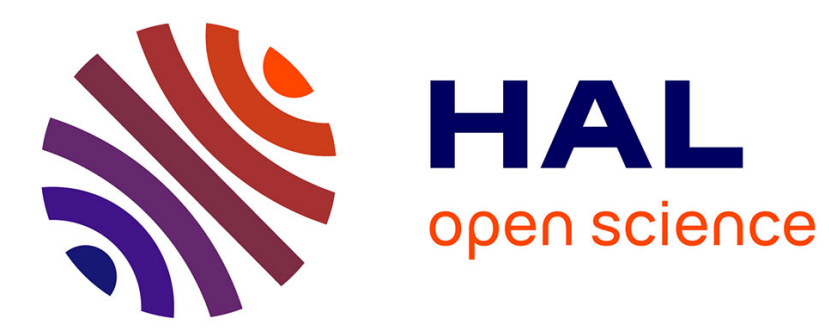

\title{
Holocene Climatic Change in the Zacapu lake basin, Michoacan, Synthesis of results.
}

Marie-Charlotte Arnauld, Sarah Metacalfe, Pierre Pétrequin

\section{To cite this version:}

Marie-Charlotte Arnauld, Sarah Metacalfe, Pierre Pétrequin. Holocene Climatic Change in the Zacapu lake basin, Michoacan, Synthesis of results.. Quaternary International, 1997, 43-44, pp.173-179. hal02881983

\section{HAL Id: hal-02881983 \\ https://hal.science/hal-02881983}

Submitted on 28 Jul 2020

HAL is a multi-disciplinary open access archive for the deposit and dissemination of scientific research documents, whether they are published or not. The documents may come from teaching and research institutions in France or abroad, or from public or private research centers.
L'archive ouverte pluridisciplinaire $\mathbf{H A L}$, est destinée au dépôt et à la diffusion de documents scientifiques de niveau recherche, publiés ou non, émanant des établissements d'enseignement et de recherche français ou étrangers, des laboratoires publics ou privés. 


\title{
HOLOCENE CLIMATIC CHANGE IN THE ZACAPU LAKE BASIN, MICHOACÁN: SYNTHESIS OF RESULTS
}

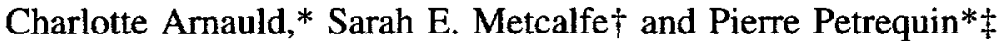 \\ *CNRS, GRAL, Université de Toulouse Le Mirail, 31058 Toulouse Cedex, France \\ $\dagger$ Department of Geography, University of Edinburgh, Edinburgh EH8 9XP, UK
}

\begin{abstract}
Following archaeological investigations of the preclassic occupation of the western part of the Zacapu lake basin, a series of analyses were made from four cores taken along a transect between the centre and the shore of the former marsh (drained at the beginning of this century). Eighteen samples were radiocarbon dated yielding ages between $8220 \pm 60$ years BP and $2170 \pm 60$ years BP (uncalibrated). Here we present a summary of the results of the sedimentological, palynological and diatom studies undertaken which indicate changes in the water level in Zacapu and changes in local climate, taking into account the effects of local volcanic activity. (C) 1997 INQUA/ Elsevier Science Ltd
\end{abstract}

\section{INTRODUCTION}

Between 1983 and 1986, a broad area of the western part of the Zacapu basin, in the state of Michoacán (Fig. 1), was the site of archaeological investigations undertaken by Charlotte Arnauld, Patricia Carot and Marie France Fauvet Berthelot of CEMCA (Centro de Estudios Mexicanos y Centroamericanos). This programme of work, called Michoacán Project 1, focused primarily on the must ancient human occupation of the peninsula of Las Lomas (the Lomas) which extends out into what is still called the Ciénega (marsh) de Zacapu even though it was drained early this century (Michelet $e t$ al., 1989; Arnauld et al., 1993). The peninsula rises to a maximum of $10 \mathrm{~m}$ above the former marsh surface.

The archaeological excavations of 1984-1986 revealed dense occupation of the area (Fig. 2) from the early years $\mathrm{AD}$ to about $\mathrm{AD} 850$ (the oldest radiocarbon date was $1961 \pm 34 \mathrm{BP}$ (INAH 331), $86 \mathrm{BC}$ to AD 68 calibrated). However, due to the artificial drainage of the marsh about 1900 , the environmental context of this settlement remained unknown which severely limited the interpretation of the archaeological remains in terms of human activities. According to statements made by some of the old Purépecha people of Zacapu and adjacent towns, it was still possible, at the end of the 19th century, to cross the marsh in canoes via open channels through the otherwise dense aquatic vegetation. A much earlier description, dated 1590 , records that on the peninsula of Las Lomas there was a small village surrounded by tilled land and maize fields, with many trees and Agave plants. There was, however, no evidence that similar land use had occurred in the pre-hispanic period. At the end of this first phase of archaeological investigation it was decided

†Present address: CNRS, UMR 9946, UFR Sciences et Techniques, la Bouloie, 25030 Besançon Cedex, France. to focus a second programme of research (Michoacán Project 2) on the question of the lacustrine palaeoenvironment (Petrequin, 1994).

The only data previously available on the Holocene environmental history of the basin came from a 14-m core from the Laguna de Zacapu, a small sub-basin fed by permanent springs lying above the marsh floor. The analyses indicated two episodes of low lake level, one about 2800-2400 BP and the second about $1100 \mathrm{BP}$ (Metcalfe, 1988). These results could not, however, simply be applied to the whole basin.

\section{SELECTION OF THE CORING SITES FOR MICHOACÁN 2}

To answer questions about the fluctuations in the level of water in the marsh, the position of the shoreline and the impact of human occupation on Las Lomas, four sampling sites (Fig. 3) were chosen:

Point 1 - a core taken about $900 \mathrm{~m}$ into the marsh, east of Las Lomas;

Point 2 - a core at the point of contact of Las Lomas with the marsh;

Point $4-$ a core located in a small marshy area within Las Lomas, close to the studied archaeological sites. Referred to below as the internal marsh;

Point 5-a series of stratigraphic samples taken from excavations at the archaeological site of Loma Alta, again in Las Lomas.

To determine the time period represented by the cores, 18 samples were radiocarbon dated ( 8 from Point 1,5 from Point 4 and 5 from Point 5). These dates revealed a significant problem as the most recent date $(2170 \pm 60$ years BP (INAH 890 7.AC 79) (calibrated 398-18 BC) from the top of Point 2 was a little older than the oldest date from the archaeological excavations at Loma Alta, 


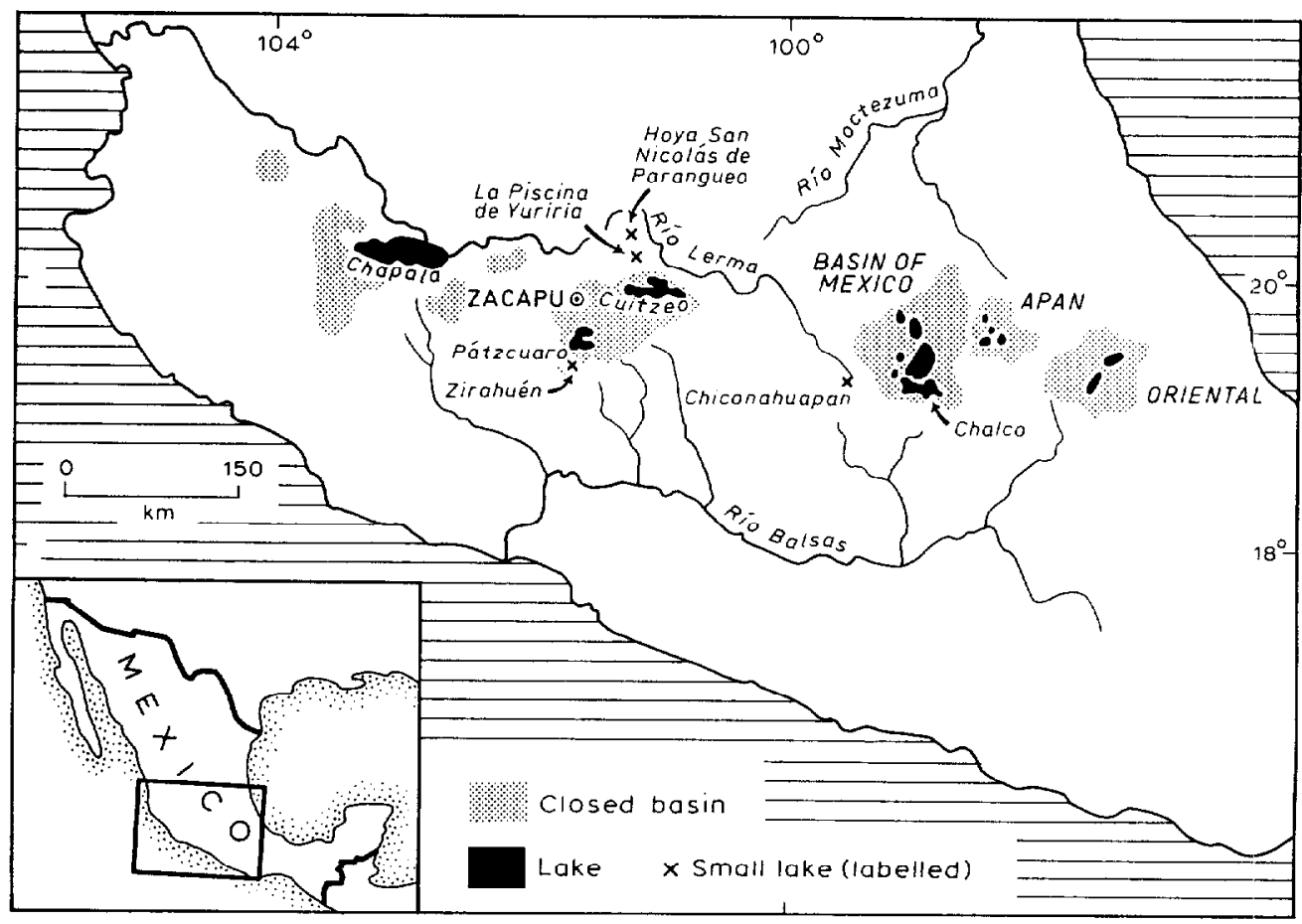

FIG. 1. Location of the Zacapu basin in central Mexico.

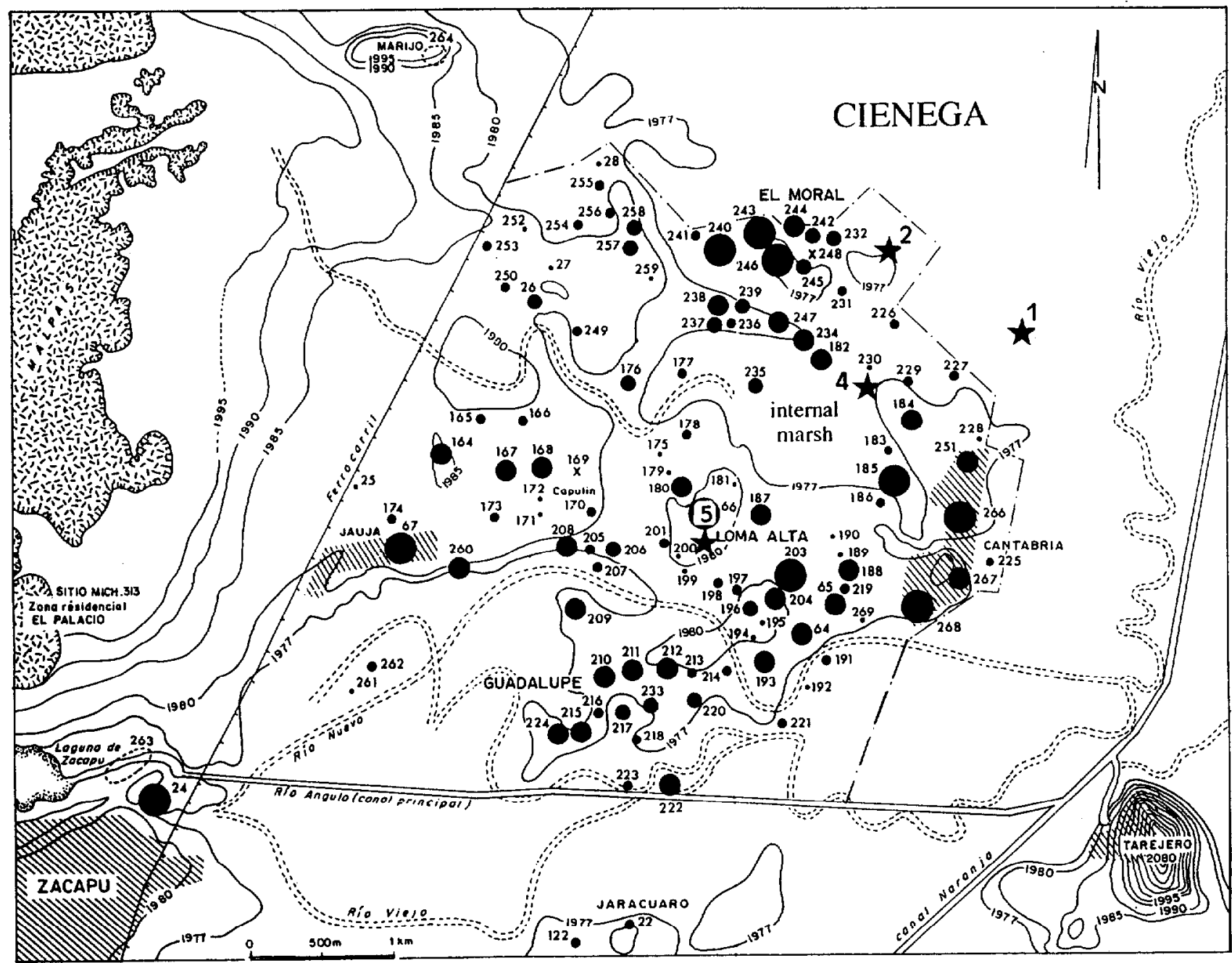

FIG. 2. Map of archaeological sites and sampling locations in the western Zacapu basin. 


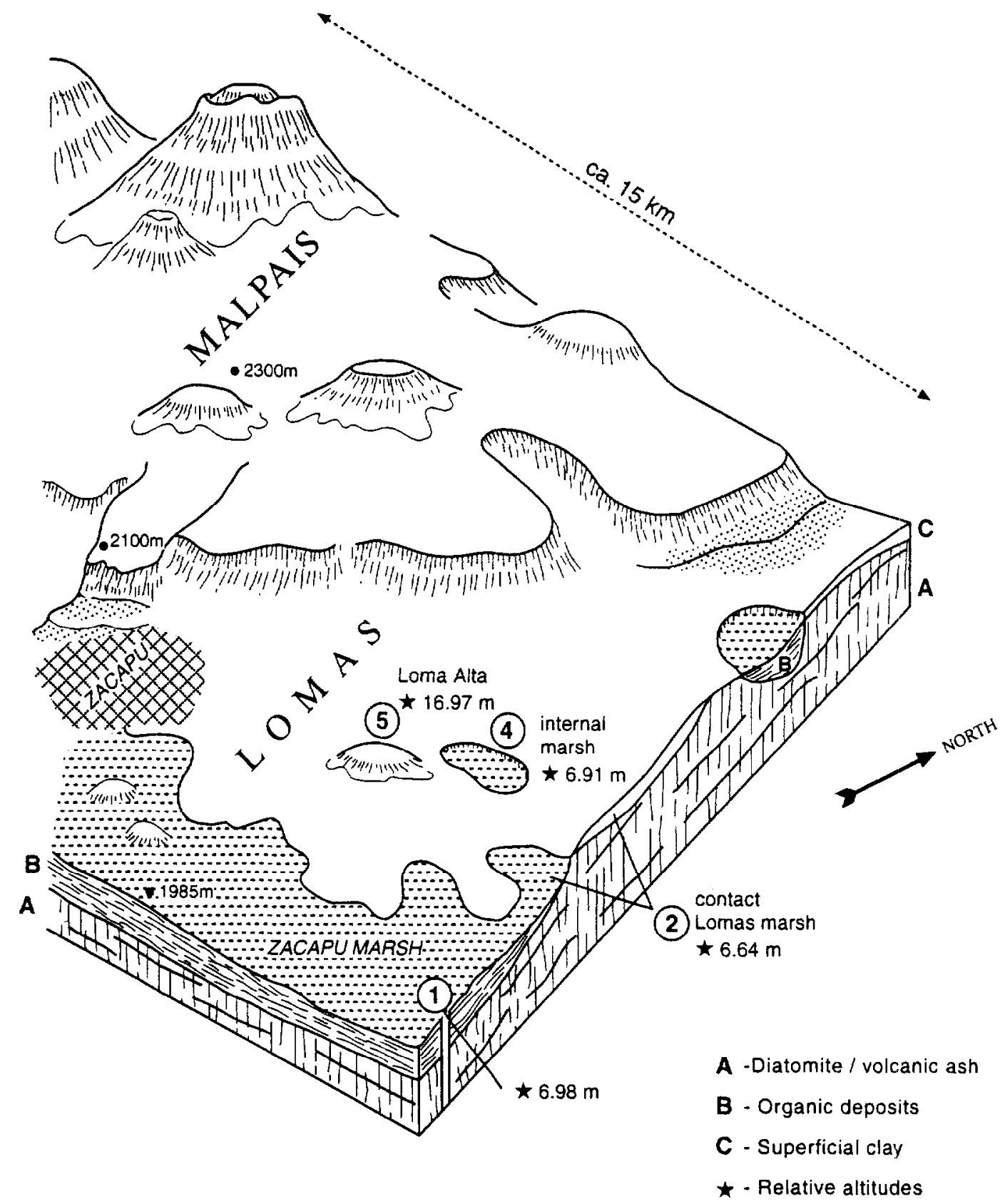

FIG. 3. Location of sampling sites for the project (Points 1, 2,4 and 5).

itself the oldest occupation site in the basin. Thus the palaeoenvironmental study of Michoacán 2 did not overlap in time with the archaeological sequence for Las Lomas. However, we must not underestimate the value of the long record provided by the cores, with the oldest date of $8220 \pm 60$ BP (INAH 890 ZAC 133-134) from $3.85 \mathrm{~m}$ in Point 1 .

Between 1988 and 1991, Susana Xelhuantzi carried out the pollen analyses, and Ma. Magdalena de Los Rios Paredes the radiocarbon dating, Herve Richard and Pierre Petrequin the sediment analyses and Sarah Metcalfe the diatom analyses. A monograph giving details of the results has been published at CEMCA in Mexico (Pétrequin, 1994). Preliminary results have been reported clsewherc (e.g. Metcalfe, 1992) and some further details are given in Lozano-Garcia and Xelhuantzi-Lopez (1997) and Metcalfe (1997). Here we provide only a summary of the palaeoenvironmental sequence we have constructed for the Zacapu basin. Correlations between cores 1, 2 and 4 have been made on the basis of the range of analyses performed and five major sedimentary episodes, or phases, have been identified across the sequences with only minor discrepancies (Fig. 4). These five phases provide the basis for the discussion below.

\section{PHASE A OF THE CIENEGA DE ZACAPU: BEFORE 8000 BP}

During this period, the marsh was characterised by a temperate, humid to sub-humid climate. Vegetation cover (Fig. 5) varied between Pinus (pine) woodlands, with Quercus (oak) and Alnus (alder) and a herbaceous understorey, and open meadows. The change to meadows 


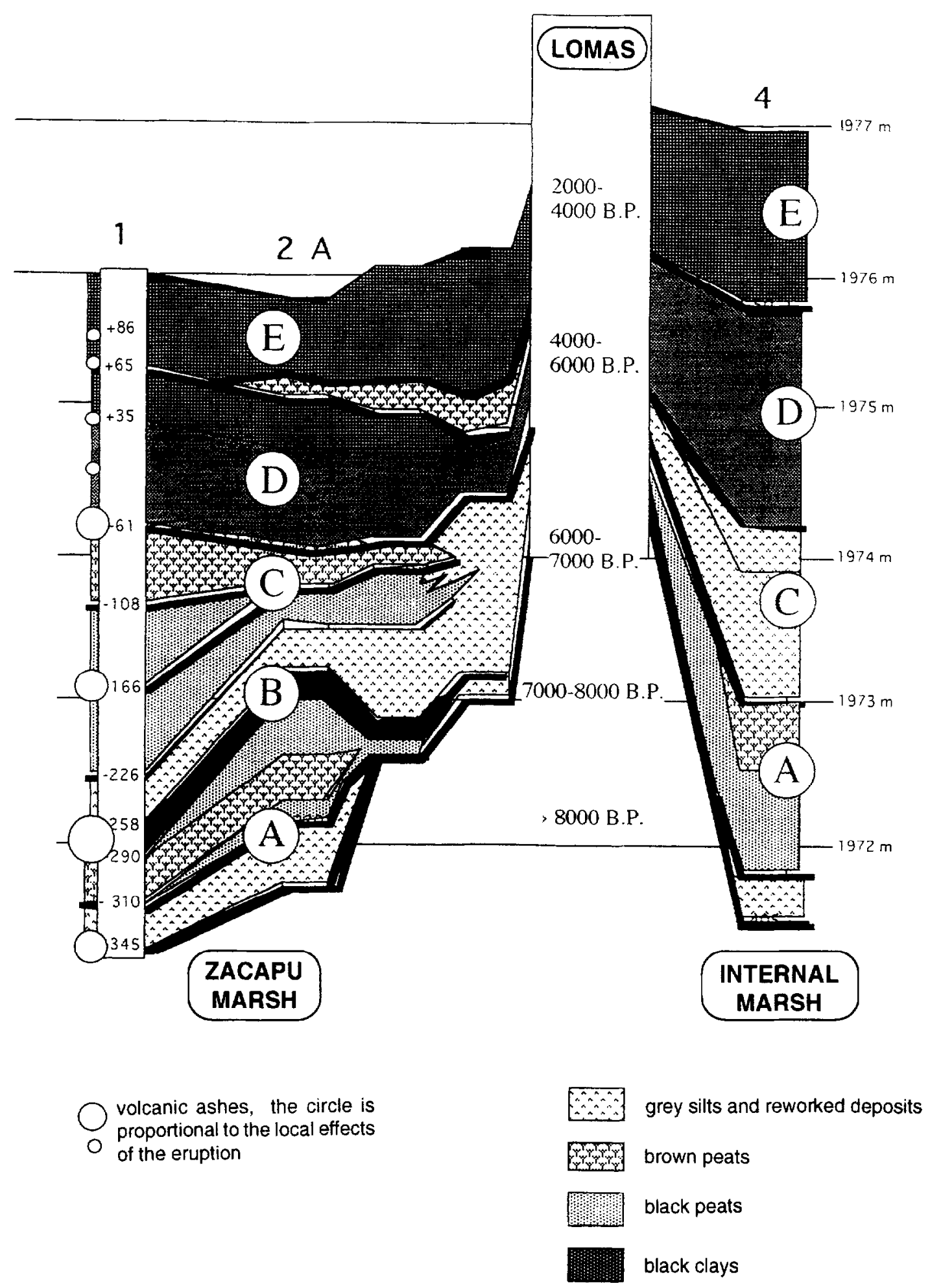

FIG. 4. Correlation of Points 1, 2 and 4 based on stratigraphic and microfossil evidence.

may reflect the partial destruction of tree cover by volcanic eruptions and ash falls, some of which are recorded in the stratigraphy.

In the marsh itself, the water was generally quite shallow and of circumneutral $\mathrm{pH}$. Aquatic macrophytes grew around the shores. There is some evidence for material being washed in from the slopes. In all three cores (1,2 and 4) sediments, pollen and diatoms yield identical records which can only be explained by the existence of a single large marsh covering all three sites. In other words, the marsh, Las Lomas and the internal marsh were not differentiated prior to $8000 \mathrm{BP}$.

\section{PHASE B: THE FORMATION OF LAS LOMAS ABOUT 8000 TO 7000 BP}

In the stratigraphic sequence, a major event interrupts 


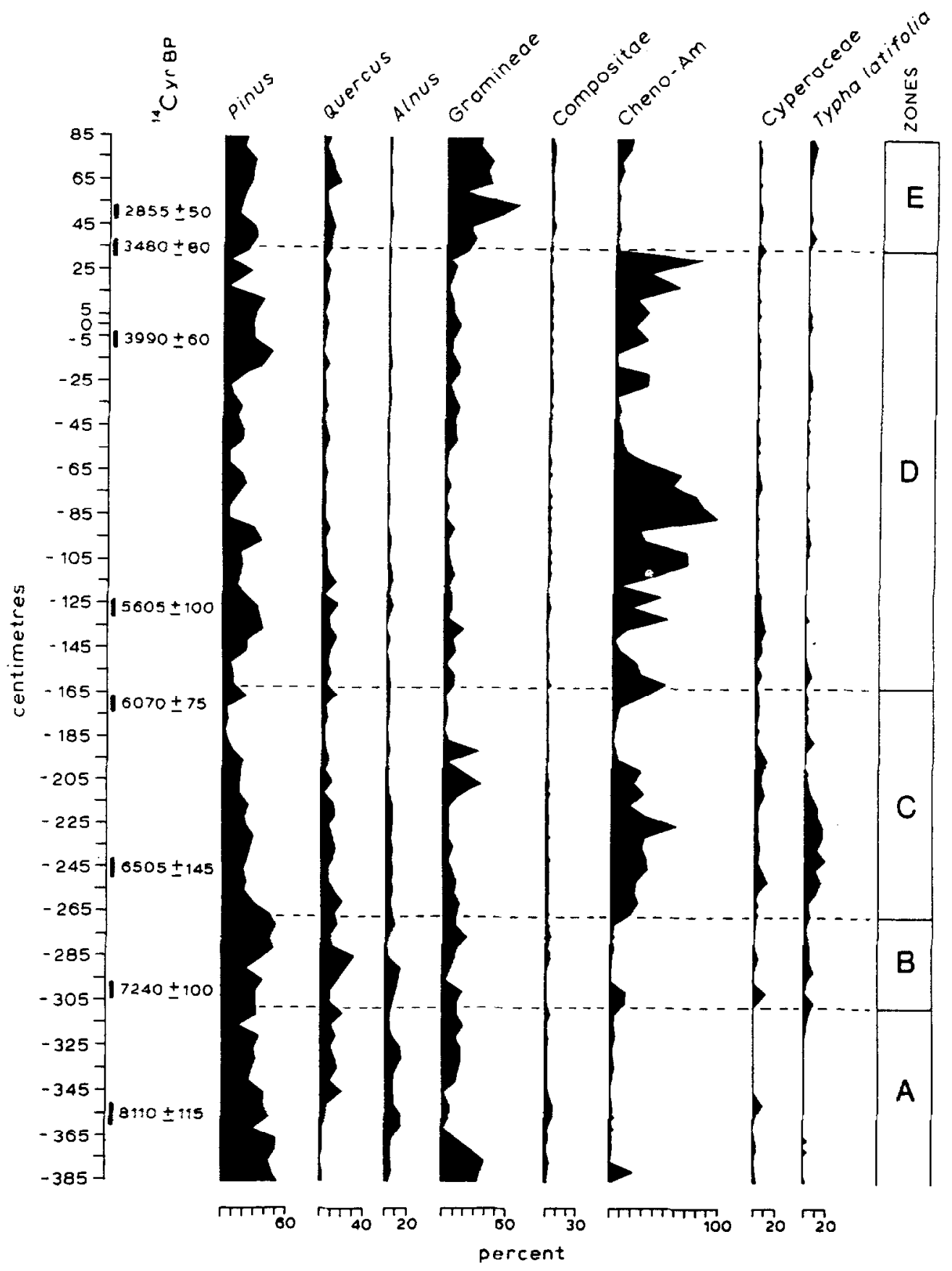

FIG. 5. Major polien types, Point 1.

the evolution of the large marsh. This event is indicated in the stratigraphy (distorted beds, volcanic ash layers), the magnetic susceptibility record (successive large peaks), the diatoms (a complete change of flora) and the pollen (Point $1-258$ to $-290 \mathrm{~cm}$, Fig. 5). It appears to have consisted of a series of volcanic eruptions, followed by tectonic activity, which had major consequences for the geomorphology and hydrology of the large marsh. To summarise, after a series of eruptions, which resulted in fires in parts of the forests in the basin, Las Lomas were uplifted dislocating the marsh. As a result, erosion was greatly intensified.
PHASE C: RETURN TO STABILITY ABOUT 7000$6000 \mathrm{BP}$

During the previous period of upheaval, the diatoms present (Fragilaria dominant, see Fig. 6, diatom zone III) indicate a shallow water marsh. Inputs of silica from the volcanic ashes, and possibly eroded material from the catchment, may account for the large increase in diatom numbers recorded in this interval. The episode of accelerated erosion lasted until about $6500 \mathrm{BP}$.

Pollen and diatoms indicate a reduction in humidity, with a very gradual change towards a semi-arid temperate climate which became very marked towards the end of the 


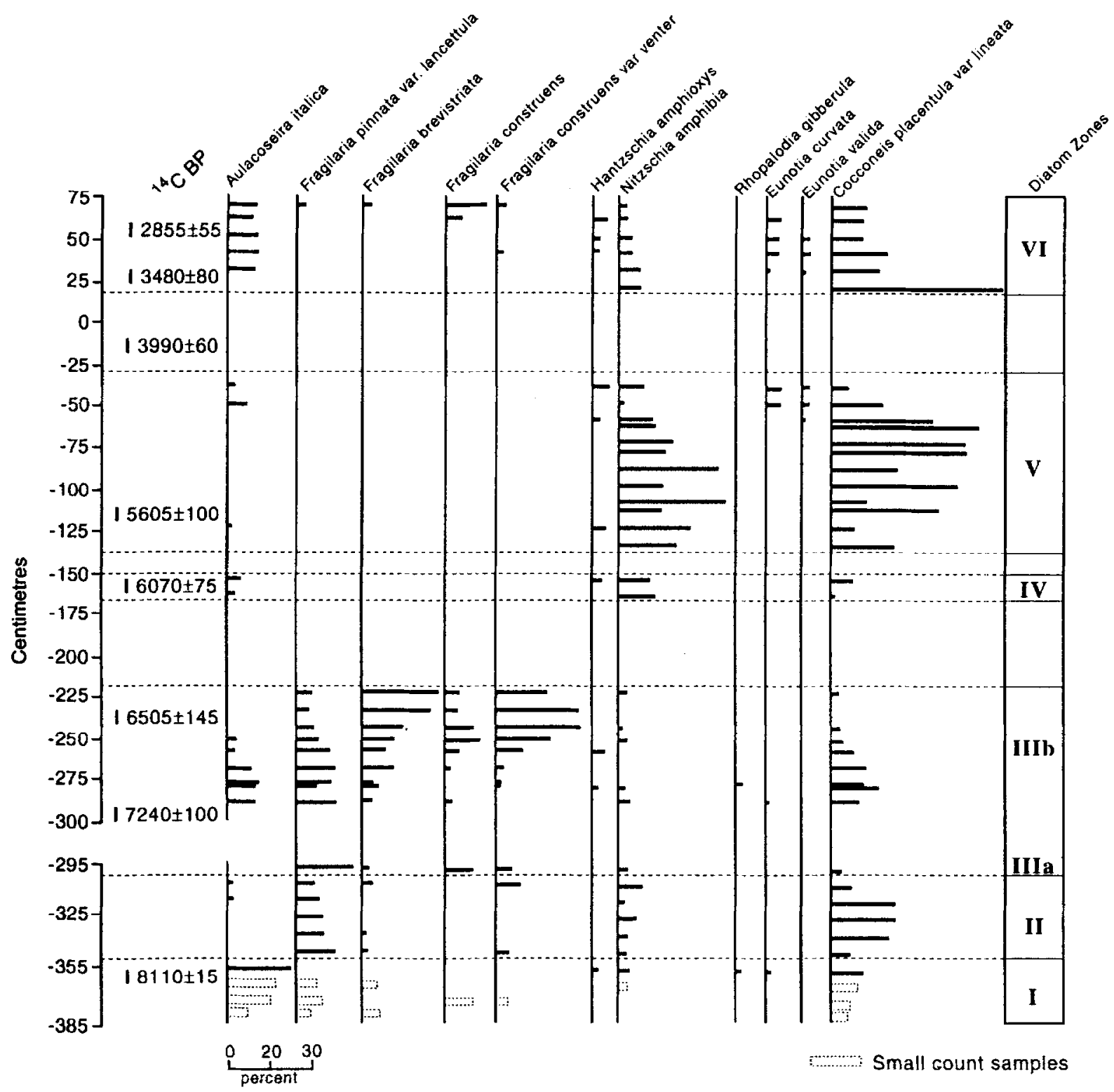

FIG. 6. Major diatom taxa, Point 1.

period. The area of the marsh was much reduced with very shallow, eutrophic water. Abundant aquatic macrophyte vegetation developed (Fig. 5), whilst grasslands covered the emergent areas of Las Lomas.

\section{PHASE D: MAXIMUM LOWERING OF THE WATER LEVEL 6000-4000 BP}

There are clear indications of a drier climate and of a shallow, alkaline marsh (Botryococcus become abundant and the diatoms indicate marked variations in osmotic pressure). About $4000 \mathrm{BP}$, the marsh expanded again and a return to sub-humid climatic conditions mark the end of Phase D.

\section{PHASE E: HUMAN IMPACT ON THE ENVIRONMENT 4000-2000 BP}

The climate became a little wetter and open water areas developed in the marsh. The pollen diagrams show that after 4000-3660 BP (2069-1660 BC) the regional forest cover was clearly affected by clearance and felling whilst a decline in Chenopodiaceae-Amaranthaceae is matched by an increase in grasses (Gramineae) (Fig. 5). In the area of the marsh and Las Lomas, the presence of humans is indicated by the occurrence of potsherds in the black clays of Point $4(-50 \mathrm{~cm})$, some exotic stones (Point 1) and a basalt blade (Point 2). There is, however, no evidence that Las Lomas were cultivated even though the first known settlements were established there at the end of the first millennium BC. The study of the three cores $(1,2$ and 4$)$ allows us to identify, at the scale of the basin as a whole, anthropogenic impacts (clearance) 2000 years before the first archaeological remains found in the basin (Las Lomas), but more or less contemporaneous with similar disturbance events in the Pátzcuaro Basin (Watts and Bradbury, 1982).

It should be reported that the sample from the archaeological site of Loma Alta yielded very poorly 
preserved pollen, with no pollen of cultivated plants (Xelhauntzi, in press). The finds dated to the first millennium AD which were excavated in 1984-1986 (and more recently in February to March 1993) yielded mainly burial items, both at Loma Alta (the oldest site) and at Guadalupe (the youngest site). Thus, although it remains a hypothesis, it appears that the occupation of Las Lomas, based on archaeological evidence, was primarily for burial purposes right through to the general abandonment of Las Lomas about AD 850-900. The cause of this abandonment does not seem to have been a rise in the level of water in the marsh, but rather may have been associated with a scarcity of water. We must, however, take into account the possible effects of socio-economic changes given that the end of the first millennium was marked in the region by the establishment of the Tarascan (Purépecha) state in the basins of Zacapu and Pálzcuaro. We do know, from documentary sources of the 16th century, that the Lomas were re-occupied and cultivated sometime before the Spanish conquest in 1521.

\section{CONCLUSIONS}

The springboard for the project Michoacán 2 was the desire to gain a better understanding of the environmental setting for the archaeological sites revealed in previous studies. Four sites were chosen which were felt to be well located to answer questions about changes in water depth, the position of the shoreline and human occupation of Las Lomas. The sequences from these sites extended into the early Holocene, providing a record of long-term environmental change. Unfortunately, there was no overlap between the major sequences (Points 1 and 4) and the archaeological record from Las Lomas. The study has, however, provided much valuable information. Earlier reconstructions of a deep lake in the basin in the early Holocene have been rejected and it is clear that marsh conditions predominated throughout. Although minor, changes in water level in the marsh would have significantly affected the availability of land for exploita- tion. The record from the Zacapu basin, in terms of both palaeoclimate and human impact, corresponds well with records from other sites in the central highlands of Mexico (Metcalfe et al., 1994) and is valuable at both the local and regional scale.

\section{ACKNOWLEDGEMENTS}

This work has been funded through support to CEMCA from the Government of France. The other major contributors to the project were Oscar Polaco, Herve Richard, Ma. Magdalena de los Rios Paredes and Susana Xelhauntzi. The authors would like to thank Keith Scurr (Hull) and Nichola Exley (Edinburgh) for redrafting some of the figures.

\section{REFERENCES}

Arnauld, C., Fauvet-Berthelot, M.-F. and Carot, P. (1993) Arqueblogia de las lomas en la cuenta lacustre de Zacapu, Cuadernos de Estudios Michoacanos, 5, CEMCA, Mexico.

Iozano-Garcia, M.S. and Xelhuantzi-Lopez, M.S. (1997). Some problems in the late Quaternary pollen records of central Mexico: Basin of Mexico and Zacapu. Quatemary Intermational, 43/44, $117-$ 123.

Metcalfe, S.E. (1988). Diatoms in a core from Laguna Zacapu, Michoacán, Mexico. In: Round, F. (ed), Proceedings of the 9th Symposium on Living and Fossil Diatoms, Bristol 1986, pp. 251-264.

Metcalfe, S.E. (1992). Changing environments of the Zacapu Basin, central Mexico: a diatom based history spanning the last 30,000 years. Research Paper 38, School of Geography, Oxford.

Metcalfe, S.E. (1997). Palaeolimnological records of climate change in Mexico - frustrating past, promising future? Quatemary International, 43/44, 111-116.

Metcalfe, S.E., Street-Perrott, F.A., O'Hara, S.L., Hales, P. and Perrott, R.A. (1994). The palaeolimnological record of environmental change: examples from the arid frontier of Mesoamerica. In: Millington, A.C. and Pye, K. (eds.), Environmental Change in Drylands, pp. 131-145. J. Wiley and Sons, New York.

Michelet, D., (Ed.) (1992). El Projecto Michoacan 1983-1987. Medio ambiente e introduction a los trabajos arqueologicos. Cuadernos de Estudios Michoacanos, 4, CEMCA, Mexico.

Pétrequin, P. (Ed.) (1994). 8000 años de la Cuenca de Zacapu, Evolution de los paisajes y primeros desmontes, Cuadernos de Fstudios Michoacanos, 6, CEMCA, Mexico.

Watts, W.A. and Bradbury, J.P. (1982). Paleoecological studies at Lake Pátzcuaro on the west-central Mexican plateau and at Chalco in the Basin of Mexico. Quaternary Research, 17, 56-70.

Xelhauntzi, S. (in press). Estudio palinológico de cuatro sitios ubicados en la cuenca de Zacapu fondo de la ciénega, contacto Loma-ciénega, pantano interno y Loma Alta. Trace, in press. 